\title{
The Role of Anxiety in Learning and Performing English in the Cadet College Classes: Bangladesh Perspective
}

Zakeya Sultana*

Department of English, ASA University Bangladesh, Bangladesh

Corresponding Author: Zakeya Sultana, E-mail: zakeyarumu@gmail.com

\section{ARTICLE INFO}

Article history

Received: April 13, 2018

Accepted: August 14, 2018

Published: October 31, 2018

Volume: 9 Issue: 5

Advance access: August 2018

Conflicts of interest: None

Funding: None

\author{
Key words: \\ Anxiety, \\ English Language, \\ Pedagogy, \\ Cadet College Students, \\ Bangladesh.
}

\begin{abstract}
Feeling of anxiety is exceedingly experienced by the English language learners throughout the world. Though the impact of anxiety on learning and performing in English has been widely studied in United States, Canada, Japan, Taiwan and many other countries; this present study, in contrast, tries to find out the reasons of anxiety in learning and performing English in the classes among the Bangladeshi cadet college students. Data has been collected through questionnaire from 30 participants from different cadet colleges in Bangladesh. Finally 10 students (one third of the total participants) were interviewed to get supportive data on their responses. An analysis of their responses indicate that preoccupied fear, peers' parents' and teachers' reactions (sometimes)hold the participants back to flourish and express themselves properly. The responses of the participants quite clearly show that peers', parents' as well as preceptors' amiable attitude towards the learners can pave the way for anxiety free learning and performance. So the findings can clearly facilitate both the students and the teachers in this respect.
\end{abstract}

\section{INTRODUCTION}

Cadet colleges are special educational institutions which aim to produce capable students to lead the country and also act as skilled army officers. Students enter into cadet college in order to lead a perfectly disciplined life. Parents also want their children to be disciplined. But in most of the cases students experience a situational shock because life starts to seem a lot more different than their presupposed ideas. Students need to follow a very strict time table to do regular work. There are also some specific hours for studying. Students are not allowed to read outside of that hours. Along with that students need to adapt themselves in almost English only environment. The medium of instruction and communication in classroom is English where except Bangla, all classed are held in English. Generally, students from two different streams enter in cadet college. One stream comes from Bangla medium background and another stream comes from English medium background. So students from English medium background face less difficulties in adapting with the situation, learning, understanding and performing in English than Bangla medium background students. Language itself becomes their valid weapon to fight whereas Bangla medium background students need extra time to get habituated in English only environment.
As students have to study only in a fixed time, they get comparatively less study time than the students of general educational institutions. Moreover, apparently it seems that the students, who come from Bangla medium background, struggle because they need to prepare the study in English within such a short period of time. Understanding each and every topic in English, study those and take preparation for the examination are of course time consuming matters. Anxiety intrudes here at this point. Horwitz, Horwitz and Cope (1991) identified foreign language anxiety as a multiplex set of self-perceptions, beliefs, feelings, and behaviors related to classroom language learning which emerge from the distinctiveness of the language learning process. Chang (2010) also agreed that anxiety plays a major role in how students acquire an L2. For that reason, Noormohammadi (2009) proclaimed that anxiety is not just an internal, private phenomenon precipitated by individual student alone, rather anxiety may be affected by external factors, such as teaching and test practices, peer interaction, overall task requirements and the instructional environment.

This research will cast light on the impact of anxiety upon learning and performing in English among cadet college students. It will also focus in which areas anxiety works and how. 


\section{RESEARCH QUESTIONS}

My research is based on three research questions and they are:

i. Is there any impact of anxiety upon leaning and performing in English among cadet college students?

ii. If yes, in which areas the anxiety works and how?

iii. What should be the pedagogic practices for reducing anxiety?

\section{LITERATURE REVIEW}

Anxiety is a very common phenomenon in the field of learning anything new, irrespective of the topics. According to Spielberger, "Anxiety is the subjective feelings of tension, apprehension, nervousness and worry associated with an arousal of the automatic nervous system" (1983: p1). It is one of the affective factors which plays a predominant role in L2 acquisition and performance (Ellis, 1994). As reported by Scovel (cited in Ellis, 1994) there are three types of anxiety. These different types anxiety are experienced by different types of learners. These three anxiety are: trait anxiety, situation-specific anxiety and state anxiety. Trait anxiety is a perennial disposition to be anxious and is an aspect of personality. Zheng (2008) also perceived that language anxiety is not merely an extra element that can be forsaken in L2 acquisition. On the contrary, it is a central emotional construct that is essential in regulating second language learning. So, this very natural and spontaneous that if students are unable to cope up with their anxiety, there is a possibility that their performance and desire to learn may be hampered. The next type of anxiety is situation-specific anxiety and it is aroused by a specific type of situation or event such as public speaking, examination and class room participation. Besides these two types of anxiety there is also state anxiety and it happens at a particular time concerning a definite situation. It is a combination of trait and situation-specific anxiety (Scovel, cited in Ellis, 1994).

Scovel (cited in Ellis, 1994) mentioned that the cause of state or situational anxiety is learner's competitive nature. Moreover, learners can also encounter anxiety as a result of fear or experience of losing oneself in the target culture and this is closely related to the idea of "culture shock" (Oxford, 1999). She mentioned that emotional regression, panic, selfpity, indecision, sadness, alienation etc. affective states associated with the source of anxiety. MacIntyre, Noels and Clement (1997) found through their research that there is a distinct relationship between language anxiety and their students' measure of achievement. But the relationship between anxiety and achievement is probably not a simple linear one. Group dynamics is a very important matter in classroom. Baily (cited in Ellis, 1985) notified that some students make apparent comparisons among each other and it helps them to get a self-image. Because, learner's self-image in comparisons with other 12 learners can impair or enhance SLA learning. Where a learner gets unsuccessful self-image by the comparison, there may be debilitating or facilitating anxiety. If the learners experience debilitating anxiety, they can quit the effort of learning. But, if the learners increase their efforts in order to compare themselves more positively with other learners, learning is enhanced (Figure 1).

In sync with the model of Baily (cited in Ellis, 1985), Yan and Horwitz (2008) mentioned second language learning as a matter of personal and ego involving endeavor where personal feelings expressly influence learners' anxiety.

Palacios (1998) scrutinized the impact of classroom environment on students' levels of foreign language anxiety and discovered that various constituents of classroom environment were connected with higher and lower levels of anxiety. Teacher's support has been considered here the most important matter. Teachers' sincere help and support toward students may help the learners to reduce the anxiety.

Cheng, Horwitz and Schallert (1999) recommended that there is a link between low self-esteem and anxiety. This low self-esteem and anxiety can be reduced by creating non-threatening and supportive instructional environments so that a heightened level of learners' self-confidence occur. Aydin (2000) discovered that students' anxiety is engendered by personal concerns such as negative self-assessment of language learning ability. In order to remove the negative perception, the students start to over use monitor to be perfect and it can be harmful for the learners. Krashen (1982) in his monitor model hypothesis argued that leaners use monitor to polish up. Monitor over-users attempt to monitor all the time and may speak hesitantly. They also try to rectify their mistakes in the middle of utterance. They are so concerned with correctness that they cannot speak with any real fluency. When students over use monitor a kind of anxiety works in them to be perfect. That thought inhibits learning and performance. Von Worde (2003) also found out that the consistent anxiety about the foreign language production and achievement impedes learning.

Monitor under users are those who have not learnt any conscious knowledge or if they have learnt it, they prefer not to use it even when situation permits. The best type of monitor users are the optimal monitor users. They do not use their conscious knowledge of grammar, where it might interfere. But if they get enough time, they will typically make the corrections to raise the accuracy of their output (Krashen, 1982). Casado and Dereshiwsky (2001) mentioned in their research that schools should adopt unconventional procedures to minimize anxiety and maximize students' achievement.

\section{METHODOLOGY}

I applied mixed method in my research because I wanted to get an outright and painstaking outcome of my research. The respondents of the study were thirty students (aged 12-16) from different cadet colleges of different classes in Bangladesh. The participants were requested to complete a questionnaire. After that the respondents were asked some specified questions along with some questions from questionnaire which needed to be explained further in order to get clear conception.

\section{Limitations of the Research}

I conducted the survey and interview for this research among thirty students and also all cadet colleges had not been in- 


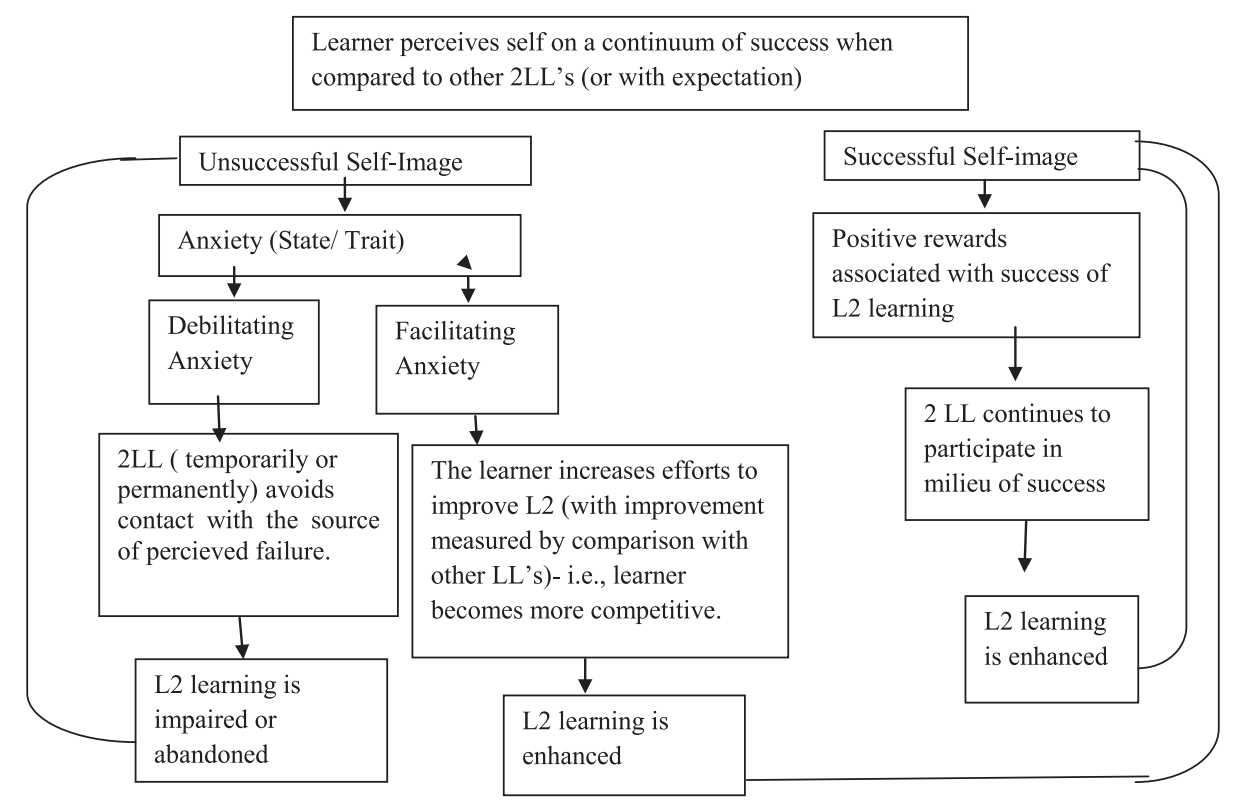

Figure 1. Competitiveness and the second language learner. (Baily, 1983, cited in Ellis, 1985:102)

cluded. It was really difficult to delineate the overall causes of anxiety experienced by the all students from all the cadet colleges in Bangladesh. Excluding the drawbacks, I tried to find ways to help the teachers, parents and students to lessen the anxiety level in order to enhance leaning and the quality of the performance.

\section{Findings and Analysis}

The ideas provoked from the questionnaire and interviews have been analyzed in relation to the following areas:

a. The fear of receiving negative evaluation.

b. The impact of communication with unknown audience.

c. Competitive mentality of parents creates anxiety among the students.

d. The influence of restricted lifestyle on learning.

e. The impact of feedback to improve their English.

f. The impact of abrupt shift towards English only environment.

g. The pedagogic implication of reducing anxiety.

\section{Quantitative Data Analysis}

\section{The fear of receiving negative evaluation}

$31 \%$ respondents strongly agreed and 57\% respondents agreed with the statement that I am afraid that the other students will laugh at me when I speak wrong English. Other respondents strongly disagreed (3\%) and disagreed (3\%) with the same statement. $21 \%$ respondents strongly agreed and $57 \%$ respondents agreed that they are afraid of the matter that their teacher is ready to correct every mistake they make while speaking and writing. Negative self-perception erupts from negative evaluation and for this reason most of the students are afraid of it. 33\% respondents strongly agreed and $44 \%$ respondents agreed that the other students are better at writing English than they are. The same has happened in case of speaking where $28 \%$ respondents strongly agreed and $58 \%$ agreed that they always feel the other students speak English better than they do. In the same way more than half of the respondents expressed their fear of making mistakes. 20\% respondents strongly disagreed and $40 \%$ respondents disagreed with the statement that I don't worry about making mistakes in class especially when the medium of instruction and communication is English. Though 40\% respondent agreed with the similar statements (Figure 2).

\section{The impact of speaking in front of the audience}

$25 \%$ respondents strongly agreed and 35\% respondents agreed with the statement that It is difficult to speak in front of the classmates, while $10 \%$ respondents strongly disagreed and $30 \%$ respondents disagreed with the same statement. When the point of unknown audience came, the response was, to some extent, similar. $15 \%$ respondents strongly agreed and $45 \%$ respondents agreed with the statement that It is difficult to speak in front of the unknown audience. Though $12 \%$ respondents strongly disagreed and $25 \%$ respondents disagreed. Sometimes they are supposed to speak without preparation and they think it is quite a problem. 34\% respondents strongly agreed and 31\% respondents agreed with the statement that I start to freak out when I have to speak without preparation in class while $6 \%$ respondents strongly disagreed and 23\% respondents disagreed. Khan and Zafar (2010) also discovered that all of the students experienced high level anxiety when they are asked to respond orally. Speaking in class in one's native tongue can often times be a daunting task, so it is easy to understand how daunting to do 
so in a language specially when a student is not entirely comfortable with and accustomed to that language (Figure 3 ).

\section{Competitive mentality of parents on the students}

$40 \%$ respondents strongly agreed and 30\% respondents agreed that their parents' expectations make them stressed out while $5 \%$ respondents strongly disagreed and $25 \%$ respondents disagreed with the same fact. The main reason of high expectation is direct comparison with the other classmates. $40 \%$ respondents strongly agreed and 30\% respondent agreed with the statement that My parents never compare me with other students while other respondents disagreed the matter by strongly disagreeing $(5 \%)$ and disagreeing $(25 \%)$ (Figure 4$)$.

\section{The influence of restricted lifestyle on learning}

$43 \%$ respondents strongly agreed and 57\% respondents agreed with the statement that I get anxious when I don't understand the topic the teacher discusses. 26\% respondents strongly disagreed and $61 \%$ respondents disagreed with the statement that I don't feel pressure to prepare very well for class while 10\% respondents agreed and 3\% respondents strongly agreed with the statement. So, this proves that understanding and taking preparation sometimes get hampered because of the English only environment (Figure 5).

\section{The impact of feedback to improve their English}

$21 \%$ respondents strongly agreed and 67\% respondents agreed with the statement that I feel overwhelmed by the number of rules I need to learn to speak and write accurate English while 3\% respondents strongly disagreed, 3\% respondents disagreed and $6 \%$ responded neither agreed nor disagreed. $90 \%$ respondents strongly agreed and $10 \%$ respondents agreed with the statement that I get upset when I don't understand what mistake the teacher is correcting (Figure 6).

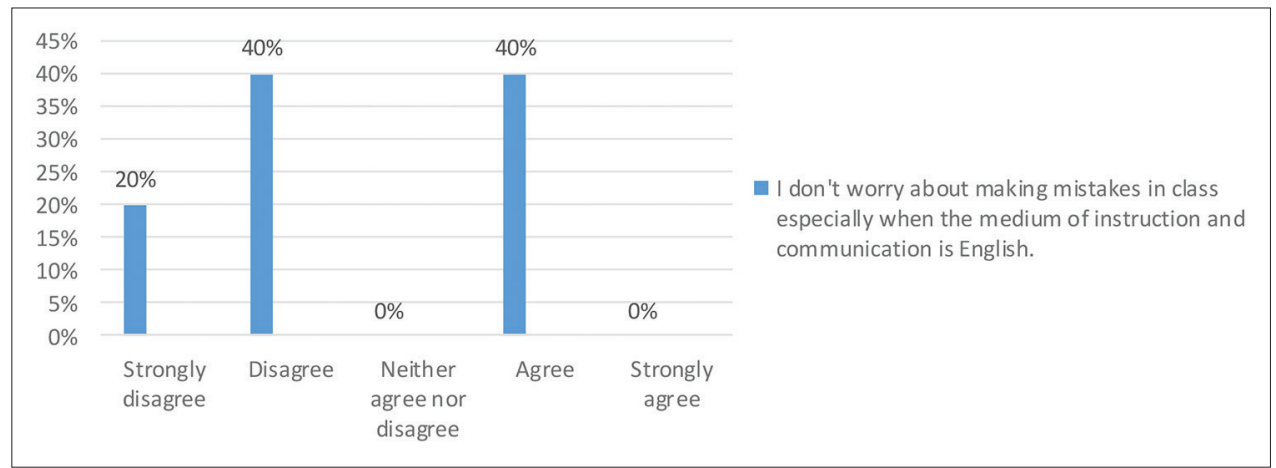

Figure 2. The fear of receiving negative evaluation

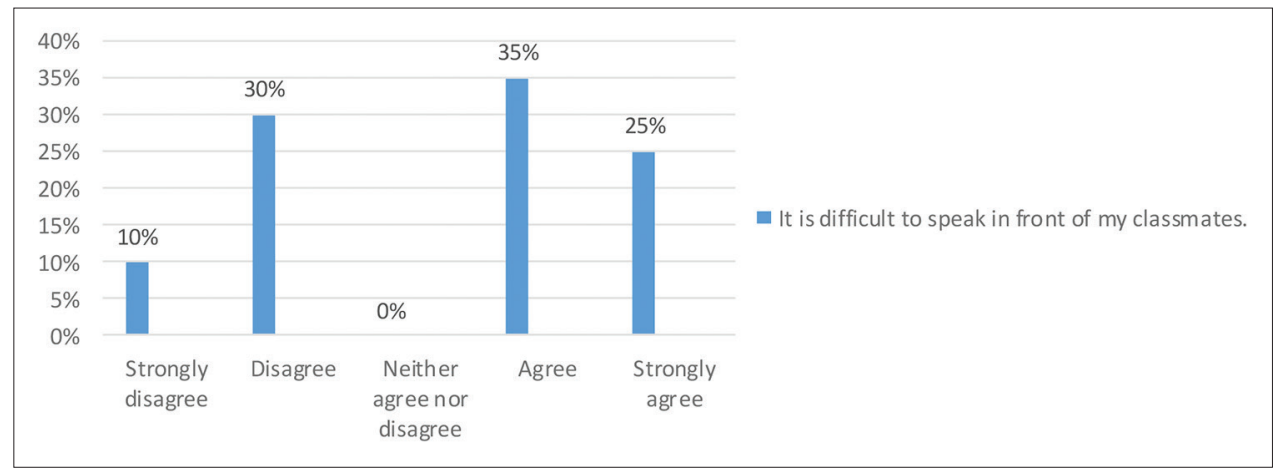

Figure 3. The impact of speaking in front of the audience

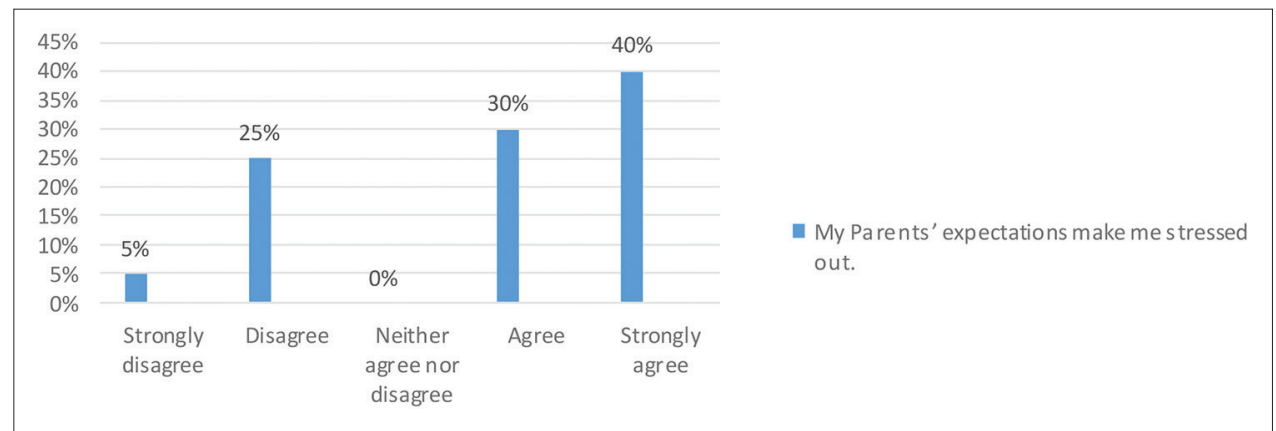

Figure 4. Competitive mentality of parents on the students 


\section{The impact of abrupt shift towards English only environment.}

$31 \%$ respondents strongly agreed and $57 \%$ respondents agreed with the statement that It scares me when I don't understand what the teacher is saying in English. Though 3\% respondents strongly disagreed, $3 \%$ respondents disagreed and $6 \%$ responded neither agreed nor disagreed.

$44 \%$ respondents strongly agreed and $16 \%$ respondents agreed with the statement that I feel very sure and relaxed in the English only environment while $40 \%$ respondents disagreed with the statement. $13 \%$ respondents strongly agreed and $65 \%$ respondents agreed with the statement that Classes (of English only environment) move so quickly that I worry about getting left behind. Though 6\% respondents strongly disagreed and $16 \%$ respondents disagreed with the statement. $27 \%$ respondents strongly disagreed and $67 \%$ respon- dents disagreed with the statement that I usually stay relaxed during tests when I have to write in English while 3\% respondents strongly agreed and 3\% respondents agreed with the statement. $76 \%$ respondents agreed and $24 \%$ respondents disagreed with the statement that In class when the medium of instruction is English, I get so nervous that I forget things I know. 66\% respondents agreed and 34\% respondents disagreed with the statement Even if I am well prepared for class, I feel anxious about it (Figure 7).

\section{Qualitative Data Analysis}

Some students have mentioned that often they take notes in a hurry but eventually understand their mistakes somehow. Sometimes they themselves are able to identify the mistakes or their friends help them to identify. As the medium of teaching is English, so any conceptual or grammatical mis-

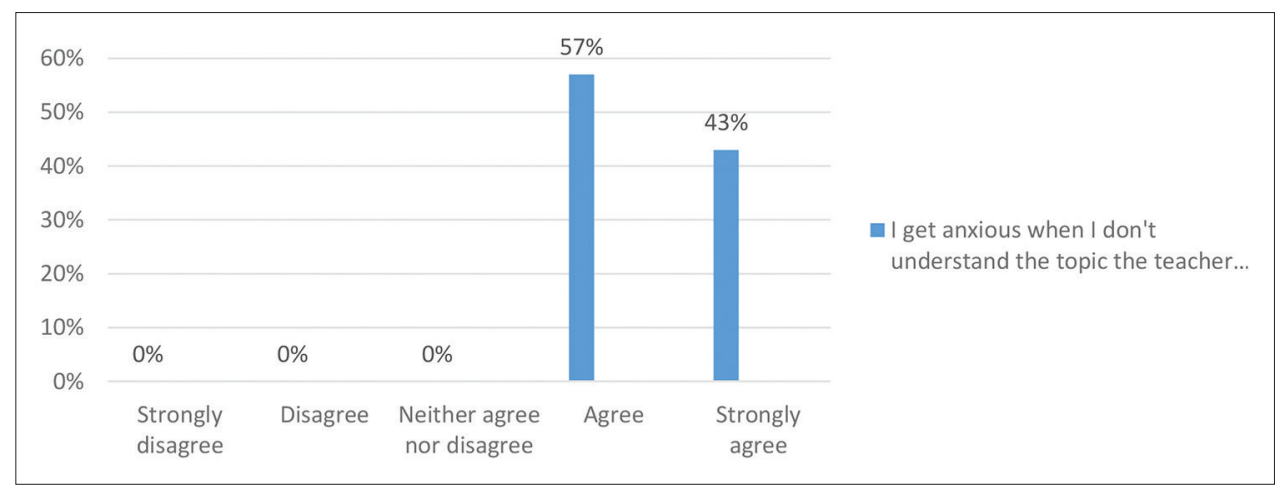

Figure 5. The influence of restricted lifestyle on learning

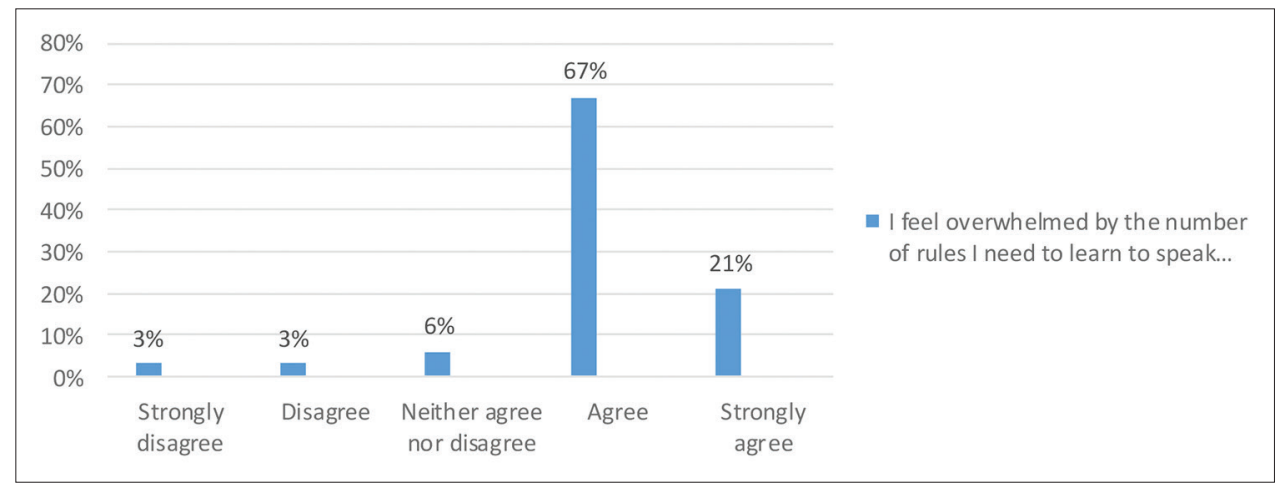

Figure 6. The impact of feedback to improve their English

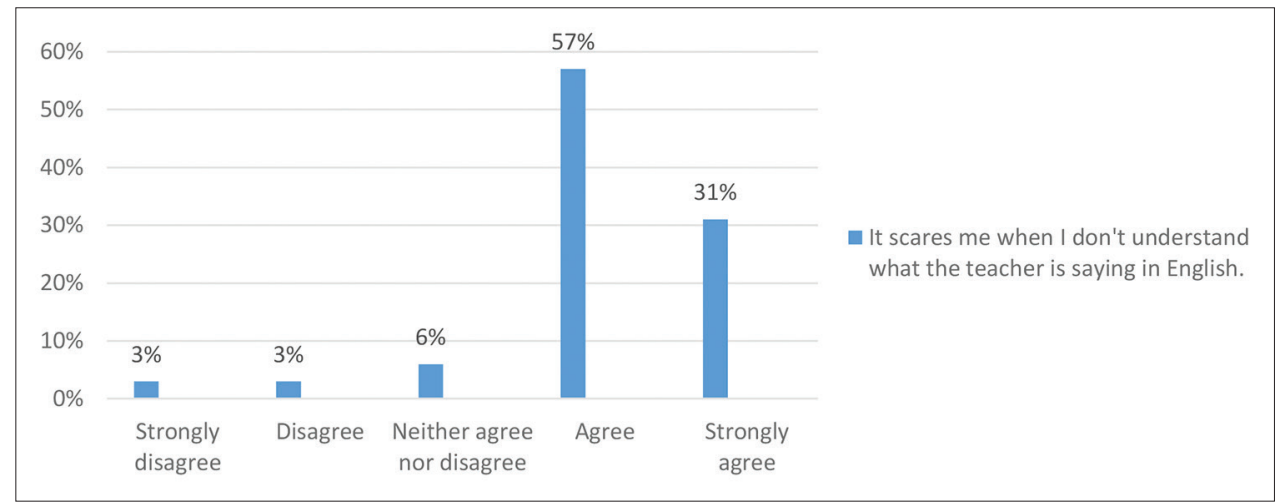

Figure 7. The impact of abrupt shift towards English only environment 
takes can happen. Some of the respondents also mentioned that teachers are generally very supportive. They try their best to clarify whatever students need to know. But this is not enough for some students. Some students feel hesitated or more specifically anxious to communicate with their teacher. Because they think teachers are the authoritative figure and they try to avoid contact. These students believe that there is always a gap between the students and the teachers.

Most of the students believe that all the students are very much talented. Some of them may come from Bangla medium background but they are talented. Moreover, they have the capabilities to cope up with this new environment. All the students are selected here are the cream of the crops and are of very good standard. So, there is no way to experience superiority complex or inferiority complex. But another minor group of students still think that there are some students who are better than them in English and get good marks in the exam. They have very enriched vocabulary which help them to express themselves more clearly. The less efficient students feel anxious about this matter and a sense of comparison and competition grow among them even if they do not want to have it. Almost all the respondents feel that exam is not an anxiety free phenomenon. Even the best of the students feel anxious when they sit for the exam irrespective of the language they are using in it. But a group of students convey that they feel twofold anxiety while they are attending in an exam. One part of anxiety occurs for the test itself and the another is derived from the thought of language. The valid ground for experiencing anxiety is whether they can write mistake free grammar or not, whether they can remember correct word according to situational need or not. Most of the respondents also convey their view that they freak out when they are asked to speak without preparation in the class. Even the students who have come from English medium background they also experience so. Because, it is a matter of mental arrangement. It needs time to mentally organize the ideas before presenting it. Along with this fact, Bangla medium background students need to think the proper English words. Some of the students have also informed that though at the outset they used to freak out but they become quite habituated with this practice by the passage of time. Some respondents have compared their fluency and word stock with their other classmates and found that that they are not that expert. So, definitely, from a sense of comparison anxiety erupts.

To some respondents, classes seem to pass very quickly because they need extra explanation (which they often ask for) to understand the topic. That dissatisfaction creates anxiety among some of the students. But the other respondents' introspection was that the teachers are really helpful all the time. If they do not understand anything in the class, the teachers are always there for them. There is no point of getting anxious in this ground.

Some of the respondents who have came from English medium background have expressed that they rather feel tensed in Bangla only environment. It is a privilege for them to speak, write and think in English. Whereas the respondents came from Bangla medium background think that it is a matter of pressure (in some cases) to speak, write and think in English all the time. And things get difficult to express in English (both, writing and speaking) because some of the respondents believe that it is not comfortable to express their understanding in English. It is almost foreign language for them. Here in cadet college it gets the status of the second language all on a sudden. So, this almost abrupt shift of the role of English language discomforts them and creates a sense of anxiety. But some respondents from senior classes have mentioned that after passing one or two years they have got habituated with English only environment, even with every rule and regulation that used to generate anxiety and used to affect their learning and performing in English only environment. Though it was not education related anxiety but that had very guaranteed effect on their learning and performance.

The respondents from English medium background feel that learning rules and applying them in the sentences is the most tiresome and confusing task. This has to be a spontaneous work. On the contrary, the respondents from Bangla medium background infers that learning rules is absolutely important. Otherwise, their English can never be the refined English. At the same time, it seems difficult to remember so many rules and apply them in the correct situation. Because if any mishap happens in applying those rules properly their English appears to be wrong. That will be the cause of getting low marks and consequently it will also make them anxious and lead to have a low notion of self-efficacy.

One respondent has mentioned that there is no point of laughing at each other's fault. The environment is so friendly. There is very strong bondage among the students. They all become their sisters and they are very supportive of each other. Instead of laughing at, they rather help each other. Another respondent has conveyed that in cadet college all the students are equally qualified. But there are some mistakes that may appear to be very funny. In that case they laugh. But they really laugh at the mistake not at the person who has made it. On the other hand, one respondent has expressed that sometimes his classmates harp on the same string. Maybe at one point he made a mistake, they keep telling that. Once or twice it is fine. But the repeated action may create anxiety in that specific person and that anxiety helps him to form a hypothesis that his English is less efficient than others.

Most of the students have reported that teachers do not interrupt to rectify their mistakes when they speak. But if the number of mistakes is high then they try to correct the mistakes along with the students' continuation. But this type of case is very rare. In writing the teachers correct every mistake and the most of the respondents believe that it is very helpful for them. While some respondents have expressed their fright about being corrected by their teachers. Because correcting the mistakes is also associated with getting less marks in the exam, parents' disappointments etc. So, beyond doubt, it creates anxiety among some of the respondents.

Most of the respondents have acknowledged that they get less time for exam preparation. This restricted time always assemble anxiety in various levels. For example: anxiety based on getting good marks, covering all the topics, having 
a clear conception on all the topics within such a short period of time. Moreover, for the Bangla medium background students, the supplementary anxiety regarding English language is always there.

Most of the students are aware of their parents' expectations. They believe that parents always want the best from their children without trying to understand that it could be an extra pressure for them. Some students also have mentioned that though parents do not say anything directly but their indirect behavior make them understand what they are actually looking for. Some parents also rebuke their children due to the poor performance in the exam. All these parental attitudes cause anxiety among students. Though a very small percentage of the students have expressed about the friendly bonding between them and their parents and from this side they do not experience any sort of anxiety.

\section{Pedagogic implication to reduce anxiety}

Overt comparison among students should be minimized. Parents should be more supportive towards their children. Teachers should create such environments where the introvert students feel free to talk to their teachers. Cooperative learning should be ensured. Anxiety is not impeding as long as it is not debilitating anxiety. Teachers should create the environment of facilitative anxiety where students are invited to have a healthy competition. If possible, preparation hour can be increased so that students do not feel that they are running out of time. Each and every student should be ensured that their mistakes would not be a matter of joke for others. Guided speaking practice can be introduced in the class.

\section{CONCLUSION}

Discipline is always appreciated. But it needs to be concerned that there should not be any negative by product of discipline. Special care should be provided to the students who experience a sudden situation shift. All they need is supportive mates, teachers and parents who will support them to enhance learning. A tone of caring needs to be there when any sort of comparison is made. Technical as well as behavioral changes are necessary to remove anxiety from the mind of the cadet college students.

\section{REFERENCES}

Aydın, B. (2000), A study of sources of foreign language classroom anxiety in speaking and writing classes. Anadolu Üniversitesi.
Casado, Matt A., and Mary I. Dereshiwsky. (2001), "Foreign Language Anxiety of University Students." College Student Journal, 35(4).

Chang, A. (2010), "Second-language listening anxiety before and after a 1-yr. intervention in extensive listening compared with standard foreign language instruction." Perceptual and motor skills, 110(2), 355-365.

Cheng, Y., Horwitz, E., and Schallert, D. (1999), “Language anxiety: Differentiating writing and speaking components." Language learning, 49(3), 417-446.

Dornyei, Z. (2007), Research Methods in Applied Linguistics. Oxford: Oxford University Press.

Ellis, R. (1985), Understanding Second Language Acquisition. Oxford: Oxford University Press.

Ellis, R. (1994), The Study of Second Language Acquisition. Oxford: Oxford University Press.

Horwitz, Elaine K., Michael B. Horwitz, and Joann Cope. (1986), "Foreign language classroom anxiety." The modern language journal, 70(2), 125-132.

Krashen, S. (1982), Principles and practice in second language acquisition. Pergamon: Oxford.

MacIntyre, Peter D., Kimberly A. Noels, and Richard, C. (1997),"Biases in self-ratings of second language proficiency: The role of language anxiety." Language learning, 47(2), 265-287.

Noormohamadi, R. (2009), "On the Relationship between Language Learning Strategies and Foreign Language Anxiety." Journal of Pan-Pacific Association of Applied Linguistics, 13(1), 39-52.

Oxford, R.L. (1999). "Anxiety and the language learner: New insights. "Affect in language learning: 58-67.

Palacios, Lisa Marie. (1998), Foreign language anxiety and classroom environment: A study of Spanish university students.Unpublished doctoral dissertation, The University of Texax, Austin.

Von Worde, R. (2003), "Students' Perspectives on Foreign Language Anxiety." Inquiry, 8(1), n1.

Yan, J., and Elaine K. (2008), "Learners' perceptions of how anxiety interacts with personal and instructional factors to influence their achievement in English: A qualitative analysis of EFL learners in China."Language Learning, 58(1), 151-183.

Spielberger, Ch. D. (1983), "Manual for the State-Trait Anxiety Inventory STAI (form Y)(“" self-evaluation questionnaire").

Zheng, Y. (2008), "Anxiety and second/foreign language learning revisited". CJNESE/RCJCE 1(1). 


\section{APPENDIXS}

Appendix-1. Questionnaire

Questionnaire for respondents

Class:........... Name of the Cadet College:

\begin{tabular}{|c|c|c|c|c|c|c|}
\hline Serial No. & Questions & $\mathbf{A}$ & B & $\mathrm{C}$ & D & $\mathbf{E}$ \\
\hline 01 & $\begin{array}{l}\text { I don't worry about } \\
\text { making mistakes in class } \\
\text { especially when the } \\
\text { medium of instruction and } \\
\text { communication is English. }\end{array}$ & $\begin{array}{l}\text { Strongly } \\
\text { disagree }(20 \%)\end{array}$ & Disagree $(40 \%)$ & $\begin{array}{l}\text { Neither } \\
\text { agree nor } \\
\text { disagree }(0 \%)\end{array}$ & Agree (40\%) & $\begin{array}{l}\text { Strongly } \\
\text { agree }(0 \%)\end{array}$ \\
\hline 02 & $\begin{array}{l}\text { It scares me when I don't } \\
\text { understand what the teacher is } \\
\text { saying in English. }\end{array}$ & $\begin{array}{l}\text { Strongly } \\
\text { disagree }(3 \%)\end{array}$ & Disagree $(03 \%)$ & $\begin{array}{l}\text { Neither } \\
\text { agrees n]or } \\
\text { disagree }(6 \%)\end{array}$ & Agree (57\%) & $\begin{array}{l}\text { Strongly } \\
\text { agree }(31 \%)\end{array}$ \\
\hline 03 & $\begin{array}{l}\text { I get anxious when I don't } \\
\text { understand the topic the } \\
\text { teacher discusses. }\end{array}$ & $\begin{array}{l}\text { Strongly } \\
\text { disagree }(0 \%)\end{array}$ & Disagree $(0 \%)$ & $\begin{array}{l}\text { Neither } \\
\text { agree nor } \\
\text { disagree }(0 \%)\end{array}$ & Agree (57\%) & $\begin{array}{l}\text { Strongly } \\
\text { agree }(43 \%)\end{array}$ \\
\hline 04 & $\begin{array}{l}\text { I keep thinking that the other } \\
\text { students are better at writing } \\
\text { English than I am. }\end{array}$ & $\begin{array}{l}\text { Strongly } \\
\text { disagree }(5 \%)\end{array}$ & Disagree (8\%) & $\begin{array}{l}\text { Neither } \\
\text { agrees nor } \\
\text { disagree }(10 \%)\end{array}$ & Agree (44\%) & $\begin{array}{l}\text { Strongly } \\
\text { agree }(33 \%)\end{array}$ \\
\hline 05 & $\begin{array}{l}\text { I always feel that the other } \\
\text { students speak English better } \\
\text { than I do. }\end{array}$ & $\begin{array}{l}\text { Strongly } \\
\text { disagree }(0 \%)\end{array}$ & Disagree (14\%) & $\begin{array}{l}\text { Neither } \\
\text { agree nor } \\
\text { disagree }(0 \%)\end{array}$ & Agree (58\%) & $\begin{array}{l}\text { Strongly } \\
\text { agree }(28 \%)\end{array}$ \\
\hline 06 & $\begin{array}{l}\text { I usually stay relaxed during } \\
\text { tests when I have to write in } \\
\text { English. }\end{array}$ & $\begin{array}{l}\text { Strongly } \\
\text { disagree }(27 \%)\end{array}$ & Disagree (67\%) & $\begin{array}{l}\text { Neither } \\
\text { agrees nor } \\
\text { disagree }(0 \%)\end{array}$ & Agree (3\%) & $\begin{array}{l}\text { Strongly } \\
\text { agree }(3 \%)\end{array}$ \\
\hline 07 & $\begin{array}{l}\text { I start to freak out when } \\
\text { I have to speak without } \\
\text { preparation in class. }\end{array}$ & $\begin{array}{l}\text { Strongly } \\
\text { disagree }(6 \%)\end{array}$ & Disagree $(23 \%)$ & $\begin{array}{l}\text { Neither } \\
\text { agrees nor } \\
\text { disagree }(6 \%)\end{array}$ & Agree (31\%) & $\begin{array}{l}\text { Strongly } \\
\text { agree }(34 \%)\end{array}$ \\
\hline 08 & $\begin{array}{l}\text { Classes (of English only } \\
\text { environment) move so } \\
\text { quickly that I worry about } \\
\text { getting left behind. }\end{array}$ & $\begin{array}{l}\text { Strongly } \\
\text { disagree }(6 \%)\end{array}$ & Disagree $(16 \%)$ & $\begin{array}{l}\text { Neither } \\
\text { agree nor } \\
\text { disagree }(0 \%)\end{array}$ & Agree (65\%) & $\begin{array}{l}\text { Strongly } \\
\text { agree }(13 \%)\end{array}$ \\
\hline 09 & $\begin{array}{l}\text { I feel very sure and relaxed in } \\
\text { the English only environment. }\end{array}$ & $\begin{array}{l}\text { Strongly } \\
\text { disagree }(0 \%)\end{array}$ & Disagree $(40 \%)$ & $\begin{array}{l}\text { Neither agree } \\
\text { nor disagree } \\
(0 \%)\end{array}$ & Agree (16\%) & $\begin{array}{l}\text { Strongly } \\
\text { Agree }(44 \%)\end{array}$ \\
\hline 10 & $\begin{array}{l}\text { In class when the medium of } \\
\text { instruction is English, I get so } \\
\text { nervous that I forget things I } \\
\text { know. }\end{array}$ & $\begin{array}{l}\text { Strongly } \\
\text { disagree } 0 \%\end{array}$ & Disagree $24 \%$ & $\begin{array}{l}\text { Neither agree } \\
\text { nor disagree } 0 \%\end{array}$ & Agree $76 \%$ & $\begin{array}{l}\text { Strongly } \\
\text { agree } 0 \%\end{array}$ \\
\hline 11 & $\begin{array}{l}\text { I feel overwhelmed by the } \\
\text { number of rules I need to } \\
\text { learn to speak and write } \\
\text { accurate English. }\end{array}$ & $\begin{array}{l}\text { Strongly } \\
\text { disagree }(3 \%)\end{array}$ & Disagree $(03 \%)$ & $\begin{array}{l}\text { Neither } \\
\text { agree nor } \\
\text { disagree }(6 \%)\end{array}$ & Agree (67\%) & $\begin{array}{l}\text { Strongly } \\
\text { agree }(21 \%)\end{array}$ \\
\hline 12 & $\begin{array}{l}\text { I am afraid that the other } \\
\text { students will laugh at me } \\
\text { when I speak wrong English. }\end{array}$ & $\begin{array}{l}\text { Strongly } \\
\text { disagree }(3 \%)\end{array}$ & Disagree $(03 \%)$ & $\begin{array}{l}\text { Neither } \\
\text { agrees nor } \\
\text { disagree }(6 \%)\end{array}$ & Agree (57\%) & $\begin{array}{l}\text { Strongly } \\
\text { agree }(31 \%)\end{array}$ \\
\hline 13 & $\begin{array}{l}\text { I am afraid that my teacher } \\
\text { is ready to correct every } \\
\text { mistakes I make while } \\
\text { speaking and writing. }\end{array}$ & $\begin{array}{l}\text { Strongly } \\
\text { disagree }(13 \%)\end{array}$ & Disagree $(03 \%)$ & $\begin{array}{l}\text { Neither } \\
\text { agrees nor } \\
\text { disagree }(6 \%)\end{array}$ & Agree (57\%) & $\begin{array}{l}\text { Strongly } \\
\text { agree }(21 \%)\end{array}$ \\
\hline 14 & $\begin{array}{l}\text { I get upset when I don't } \\
\text { understand what mistake the } \\
\text { teacher is correcting. }\end{array}$ & $\begin{array}{l}\text { Strongly } \\
\text { disagree }(0 \%)\end{array}$ & Disagree $(0 \%)$ & $\begin{array}{l}\text { Neither agree } \\
\text { nor disagree } \\
(0 \%)\end{array}$ & Agree (10\%) & $\begin{array}{l}\text { Strongly } \\
\text { agree }(90 \%)\end{array}$ \\
\hline 15 & $\begin{array}{l}\text { I don't feel pressure to } \\
\text { prepare very well for class. }\end{array}$ & $\begin{array}{l}\text { Strongly } \\
\text { disagree }(26 \%)\end{array}$ & Disagree (61\%) & $\begin{array}{l}\text { Neither } \\
\text { agree nor } \\
\text { disagree }(0 \%)\end{array}$ & Agree (10\%) & $\begin{array}{l}\text { Strongly } \\
\text { agree }(3 \%)\end{array}$ \\
\hline 16 & $\begin{array}{l}\text { Even if I am well prepared for } \\
\text { class, I feel anxious about it. }\end{array}$ & $\begin{array}{l}\text { Strongly } \\
\text { disagree }(0 \%)\end{array}$ & Disagree (34\%) & $\begin{array}{l}\text { Neither } \\
\text { agree nor } \\
\text { disagree }(0 \%)\end{array}$ & Agree (66\%) & $\begin{array}{l}\text { Strongly } \\
\text { agree }(0 \%)\end{array}$ \\
\hline
\end{tabular}




\begin{tabular}{|c|c|c|c|c|c|c|}
\hline Serial No. & Questions & $\mathbf{A}$ & B & $\mathbf{C}$ & D & $\mathbf{E}$ \\
\hline 17 & $\begin{array}{l}\text { My Parents' expectations } \\
\text { make me stressed out. }\end{array}$ & $\begin{array}{l}\text { Strongly } \\
\text { disagree }(5 \%)\end{array}$ & Disagree $(25 \%)$ & $\begin{array}{l}\text { Neither agree } \\
\text { nor disagree } \\
(0 \%)\end{array}$ & Agree (30\%) & $\begin{array}{l}\text { Strongly } \\
\text { agree }(40 \%)\end{array}$ \\
\hline 18 & $\begin{array}{l}\text { My parents never compare me } \\
\text { with other students. }\end{array}$ & $\begin{array}{l}\text { Strongly } \\
\text { disagree }(5 \%)\end{array}$ & Disagree $(25 \%)$ & $\begin{array}{l}\text { Neither agree } \\
\text { nor disagree } \\
(0 \%)\end{array}$ & Agree (30\%) & $\begin{array}{l}\text { Strongly } \\
\text { agree }(40 \%)\end{array}$ \\
\hline 19 & $\begin{array}{l}\text { It is difficult to speak in front } \\
\text { of my classmates. }\end{array}$ & $\begin{array}{l}\text { Strongly } \\
\text { disagree }(10 \%)\end{array}$ & Disagree $(30 \%)$ & $\begin{array}{l}\text { Neither } \\
\text { agree nor } \\
\text { disagree }(0 \%)\end{array}$ & Agree (35\%) & $\begin{array}{l}\text { Strongly } \\
\text { agree }(25 \%)\end{array}$ \\
\hline 20 & $\begin{array}{l}\text { It is difficult to speak in front } \\
\text { of the unknown audience. }\end{array}$ & $\begin{array}{l}\text { Strongly } \\
\text { disagree }(12 \%)\end{array}$ & Disagree $(28 \%)$ & $\begin{array}{l}\text { Neither agree } \\
\text { nor disagree } \\
(0 \%)\end{array}$ & Agree(45\%) & $\begin{array}{l}\text { Strongly } \\
\text { agree }(15 \%)\end{array}$ \\
\hline
\end{tabular}

\section{APPENDIX 2: RESPONDENTS' INTERVIEW}

\section{Interview questions}

1. Do you think anxiety is a personal trait? Or, it comes along with the situation?

2. Why do you think so?

3. Predominantly what factors make you anxious?

4. Is there any roles of parents to help you to decrease your anxiety? If yes, how?

5. What could be the role of teachers to decrease your anxiety?

\section{Transcription of the Respondents' Interview}

\section{Student-1}

I think to me it comes along with situation in some cases like public speaking. Anxiety comes from the sudden flow of rules and regulations. I should say that the environment here is favourable to learn English. Formally informally we always need to use English. Sometimes we need to use them without knowing their meaning. For example, "escort". We did not know the meaning when we first used it. But by using it we know the meaning from action. In learning I think I do not get the proper time that I need. I am from Bangla medium background. So, I think this subject needs extra care from me. There anxiety comes. But the classroom environment is friendly. So we don't be anxious there. My parents are very supportive. I have no complain about my parents.

\section{Student 2}

I think anxiety is a personal trait. It is in my nature. I feel anxiety during exam, public speaking and sometimes during class. I think there are so many pressure in this environment. It is so difficult to perform each and every task almost every day. Being an introvert I try to avoid contact with my teachers as much as I can do. English only environment creates anxiety in me. Sometimes I do not understand lectures. I become anxious then. I discuss it with my friends. I think, my parents expect something good from me. I try to do well but I think they want more than that. That also creates anxiety. They should be understanding.

\section{Student-3}

I think anxiety can be experienced in both ways. It is a personal trait and sometimes situation also allows students to experience anxiety. But I also think it becomes all right by the passage of time. Students sometimes think they cannot bear the pressure of rules and regulations along with English only environment. But I have experienced, most of the students get accustomed to the environment. I have found my teachers very helpful. They help us whenever we need. There are some good students from English medium background and I try to compete with them. It helps when I want to really learn something. But it is true that the time we get to study is comparatively less than the students of other institutions. It sometimes creates anxiety among us. Sometimes parents are not satisfied with our achievements. They compare us in a negative way with other students no matter how much we try. It seems that we will never actually be able to satisfy them.

\section{Student-4}

I think it is both. I feel very anxious when I compare myself with other students. It is natural because it is very prominent that some students are better than me in English reading, writing, speaking and listening. They have very enriched vocabulary. They always get good mark. The medium of instruction becomes their plus point when I need to struggle to understand the subject matter because of it. Some teachers are not efficient to make us understand easily and the obscurity regarding subject matter makes me anxious. Parents' mentality to compare with other students also make me anxious because I am already trying to improve myself. They do not understand it. They do not see the good part.

\section{Student- 5}

To me anxiety is the combination of both. I feel anxious when I have to prepare my lesson within a short period of time. I am from Bangla medium background. It takes time to understand the topic in English and then form the idea which is being discussed in the class. For examination, I need to take preparation in English. Sometimes I think in Bangla to 
understand the topic. Then I translate it into English. It is a time consuming matter. I do not get that much time. This is a matter of anxiety for me. Sometimes if I make any mistake, my mates repeatedly mention it to make fun. It hurts because they try to point out my vulnerability. This surely creates anxiety. I think teachers are very friendly. I also get good support from my parents.

\section{Student-6}

I think Anxiety comes from situation. For example, I always become anxious because I do not get enough time to study. There is always a rush to complete the next task. But I think my mates are very friendly and supportive. There is a strong bondage among us. We always help each other to be better. Sometimes my friends laugh at my mistakes which seems to be funny. But I understand that they are laughing at my mistake not at me. Some items seem to be very difficult to understand. We ask teachers about that. Yet, sometimes, they cannot make us understand easily. I think sometimes if they make the topic easy it would be better for us. Parents need to be supportive and understand the state of mind of their children rather complaining about the progress.

\section{Student-7}

According to me anxiety derives from situation. I have come from Bangla medium background. Now I am studying in English only environment. I am not accustomed to listen to English all the time. There is a sudden shift. This shift is enough to create anxiety. Moreover, when there is oral performance in front of the whole class I feel very anxious. Even if I have preparation on that it is tough for me. I become blank. Sometimes receiving negative evaluation from teachers creates anxiety. When teachers mark the mistakes in exam script is also a matter of anxiety. Because those mistakes will decrease the mark. Parents will be hurt if the performance in exam is poor. Experiencing anxiety is an accumulative process. I think teachers and parents both should be encouraging.

\section{Student-8}

Anxiety is originated in a specific situation. For example: test. During test we actually get anxious. I have come from Bangla medium background. During test I always face twofold anxiety. Test itself is enough to create anxiety among students. Moreover, I have to write all the questions in all subjects in English except Bangla. So, whether I can use the correct word according to the situation or not, whether I can apply the correct term or not, whether I will be able to express my thoughts and ideas clearly or not create anxiety in me. I think teachers are really very cooperative so are my parents.

\section{Student-9}

I think anxiety is a personal trait. But it can be overcome. I have come here from Bangla medium background. At first I used to freak out at almost everything. But I have become habituated to those facts. When I look back I understand that encountering those situations more helped me to be anxiety free. My teachers and parents both are very supportive.

\section{Student-10}

I think anxiety comes from a specific situation. I have come here from English medium background. I do not think apart from exam there is any source of anxiety. My teachers are very caring and my parents are also. 